\title{
EVALUATION OF CULTURE MEDIA FOR COUNTS OF BIFIDOBACTERIUM ANIMALIS SUBSP. LACTIS BB 12 IN YOGHURT AFTER REFRIGERATED STORAGE
}

\author{
Luciano Fachin; Juliana Moryia; Ana Lourdes Neves Gândara'; Walkiria Hanada Viotto ${ }^{1 *}$ \\ ${ }^{1}$ Departamento de Tecnologia de Alimentos, Faculdade de Engenharia de Alimentos, Universidade Estadual de Campinas, \\ Campinas, SP, Brasil
}

Submitted: August 23, 2006; Approved: February 20, 2008.

\begin{abstract}
The agar RCPB pH5 has been considered a good alternative for counts of Bifidobacterium in yoghurt. However, during the refrigerated storage of yoghurt it is extremely difficult to count this microorganism due to the size of the colonies, which are so small they require the aid of a stereoscope to count them. Another agar, MRS-LP, has been also recommended for counts of Bifidobacterium in the presence of yoghurt bacteria. This study evaluated the supplementation of RCPB pH5 agar with dehydrated liver extract and the salts $\mathrm{KH}_{2} \mathrm{PO}_{4}, \mathrm{~K}_{2} \mathrm{HPO}_{4}, \mathrm{FeSO}_{4} 7 \mathrm{H}_{2} \mathrm{O}, \mathrm{MnSO}_{4} \mathrm{H}_{2} \mathrm{O}$ and $\mathrm{MgSO}_{4} 7 \mathrm{H}_{2} \mathrm{O}$, aiming at improving the differentiation of Bifidobacterium in yoghurt after refrigerated storage, and also evaluated the selective count of Bifidobacterium in yoghurt using the agar MRS-LP. The agar MRS-LP presented the same cell recovery as non-fortified $\mathrm{RCPB} \mathrm{pH} 5$ agar, used as a standard medium, thus being considered a good option for counts of Bifidobacterium in yoghurt. The fortified RCPB pH5 also presented the same recovery as the standard RCPB pH5 medium, however, the addition of dehydrated liver extract to the RCPB pH5 agar considerably increased the size of the Bifidobacterium colonies after refrigerated storage, making differentiation of the colonies much easier and reliable when compared to the standard non-fortified RPCP pH5. The addition of the salts $\left(\mathrm{KH}_{2} \mathrm{PO}_{4}, \mathrm{~K}_{2} \mathrm{HPO}_{4}, \mathrm{FeSO}_{4} 7 \mathrm{H}_{2} \mathrm{O}, \mathrm{MnSO}_{4} \mathrm{H}_{2} \mathrm{O}\right.$ and $\left.\mathrm{MgSO}_{4} 7 \mathrm{H}_{2} \mathrm{O}\right)$ had no influence on the performance of the $\mathrm{RCPB} \mathrm{pH} 5$ agar.
\end{abstract}

Key-words: count, Bifidobacterium, yoghurt, refrigerated storage.

\section{INTRODUCTION}

Currently much attention is given to the use of probiotic yoghurts due to their potential benefits to human health (2). It is recommended that each product should indicate the minimum daily amount required for it to confer health benefit(s) based on in vitro (animal) and human studies (3). However, the yoghurt-manufacturing conditions are far from favourable for the survival of Bifidobacterium, resulting in a low number of viable cells during refrigerated storage. In addition, the lack of a standard method for the count of Bifidobacterium in the presence of yoghurt bacteria reduces confidence in the technology of production of these yoghurts. Few methods are efficient to correctly count Bifidobacterium in the presence of yoghurt cultures, causing difficulties in the quality control (11).

Onggo and Fleet (8) used RCPB agar to isolate and differentiate Bifidobacterium spp., L. bulgaricus and $S$. thermophilus in yoghurts. Rybka and Kailasapath (10) proposed adjustment of the $\mathrm{pH}$ of the agar to 5, to avoid development of the non-lactic flora. Ghodussi and Robinson (4) obtained good results with RCPB agar for the differential count of Bifidobacterium in yoghurts. On the other hand, Payne, Morris and Beers (9) did not get good differentiation between the Bifidobacterium colonies and those of the yoghurt in this agar, the differential count of Bifidobacterium not being possible. In laboratory tests by the present authors, RCPB pH5 agar gave excellent differentiation and recovery of Bifidobacterium in

*Corresponding Author. Mailing address: Department of Food Technology, CP 6121, Faculty of Food Engineering, State University of Campinas, Brazil. Tel.: +55-019-3521-3988 Fax: +55 019-3289-3617. E-mail: walkiria@fea.unicamp.br 
relation to the yoghurt cultures when the count was made soon after fermentation of the yoghurt, and also when inoculated by spreading the individual microorganisms, grown separately, on the surface of the agar (7). However, when this agar was used to count Bifidobacterium in yoghurts during refrigerated storage, the diameter of the colonies was so small, they could only be visualised with the aid of a stereoscope, magnifying from 15 to 20 times. Thus the capacity of Bifidobacterium to develop in $\mathrm{RCPB}$ pH5 agar under conditions of cell stress, as occurs during refrigerated storage, was considerably lower, indicating that this agar is not a good option for the count of Bifidobacterium in yoghurts during the shelf life.

Beehrens (1) described a medium containing a combination of low $\mathrm{pH}$ and propionic acid which makes the medium both elective and selective for all species of Bifidobacterium. When propionic acid was added to Columbia agar at $\mathrm{pH} 5.0$ it enhanced the growth of bifidobacteria. Colonies sometimes reached 2 $\mathrm{mm}$ in diameter compared with only $0.2-0.5 \mathrm{~mm}$ on the control medium at $\mathrm{pH} 5.0$ without propionic acid. Lapierre, Undeland and Cox (5) proposed the use of lithium chloride and sodium propionate to inhibit yoghurt bacteria in association with lactose-cystine-liver agar, in order to count Bifidobacterium in fermented milk products. Vinderola and Reinheimer (11) used these inhibitors associated with MRS agar, to count Bifidobacterium in yoghurts.

Based on the fortifications proposed by Teraguchi, Uehara, Ogasa and Mitsuoka (1978) in their study on the selective count of Bifidobacterium, as described in Laroia and Martin (6), the objective of this research was to improve the differentiation of RCPB pH5 agar and evaluate the use of MRS-LP agar (11) for counts of Bifidobacterium in yoghurt after refrigerated storage.

\section{MATERIALAND METHODS}

\section{Cultures}

Pure freeze dried cultures of Bifidobacterium animalis subsp. lactis $\mathrm{Bb} 12$ (B. animalis $\mathrm{Bb}$ 12, Chr. Hansen Indústria e Comércio Ltda, Valinhos, SP), Streptococcus thermophilus A (S. thermophilus, old brand Wiesby Starter Cultures \& Media, current Danisco Brasil Ltda, Cotia, SP), Lactobacillus delbrueckii subsp. bulgaricus 18 (L. bulgaricus, old brand Wiesby Starter Cultures \& Media, current Danisco Brasil Ltda, Cotia, SP) and $S$. thermophilus TA 040 and L. bulgaricus LB 340, both provided by Rhodia Food (current Danisco Brasil Ltda, Cotia, SP) were used.

\section{Culture Media \\ MRS agar}

MRS agar (DIFCO or MERCK) was used as the standard agar for the pure cultures of $B$. animalis $\mathrm{Bb} 12$. The plates were maintained at $37^{\circ} \mathrm{C}$ for 72 hours under anaerobic conditions (Anaerogen ${ }^{\circledR}$ - anaerobiosis generator from Oxoid).

\section{RCPB pH5 agar}

The RCA (OXOID) agar and the Prussian Blue dye (SIGMAALDRICH) were separately sterilised at $121^{\circ} \mathrm{C}$ for 15 minutes, then cooled to $50^{\circ} \mathrm{C}$ and mixed aseptically. An amount of the Prussian Blue dye equivalent to $0.03 \%$ by weight of the final agar was dissolved in distilled water $(12 \%$ by volume of the agar), the rest of the water ( $88 \%$ by volume) being used to dissolve the commercial RCA agar ingredients, which was subsequently adjusted to $\mathrm{pH} 5$. The dye solution was not adjusted to $\mathrm{pH} 5$.

\section{MRS-LP agar}

The MRS agar (OXOID or MERCK) was dissolved in an amount of water equivalent to $93 \%$ of the agar final volume and sterilised at $121^{\circ} \mathrm{C}$ for 15 minutes. The inhibitory agents $(0.2 \mathrm{~g} /$ $\mathrm{L}$ lithium chloride and $0.3 \mathrm{~g} / \mathrm{L}$ sodium propionate) were dissolved in the remaining $7 \%$ of the water and this solution sterilised using a $0.22 \mathrm{~mm}$ filter. The filtered solution of antimicrobial agents was carefully mixed with the MRS agar at $50^{\circ} \mathrm{C}$ in a laminar flow chamber, avoiding the incorporation of air.

\section{Fortified RCPB pH5 agar}

The RCPB pH5 agar was fortified with the following salts: $\mathrm{KH}_{2} \mathrm{PO}_{4}(1 \mathrm{~g} / \mathrm{L}), \mathrm{K}_{2} \mathrm{HPO}_{4}(1 \mathrm{~g} / \mathrm{L}), \mathrm{FeSO}_{4} 7 \mathrm{H} 2 \mathrm{O}(0.01 \mathrm{~g} / \mathrm{L})$, $\mathrm{MnSO}_{4} \mathrm{H}_{2} \mathrm{O}(0.01 \mathrm{~g} / \mathrm{L})$ and $\mathrm{MgSO}_{4} 7 \mathrm{H}_{2} \mathrm{O}(0.2 \mathrm{~g} / \mathrm{L})$ and also with the dehydrated liver infusion $(150 \mathrm{~mL} / \mathrm{L})$. The liver infusion was prepared according to Laroia and Martin (6) and sterilised separately at $121^{\circ} \mathrm{C} / 15$ minutes (both the precipitate and the supernatant of the extraction were sterilised in the same flask). For the subsequent addition to the agar, the sterilised extract was left to decant at room temperature, and the supernatant $(150 \mathrm{~mL} / \mathrm{L})$ added to the RCA agar, already containing the salts and the water, in a laminar flow chamber. The $\mathrm{pH}$ of the RCA agar containing the salts, liver extract and water was adjusted to 5. The volume of water used to dissolve the Prussian Blue dye was $12 \%$ of the total volume of the RCA agar. For example: to produce $300 \mathrm{~mL}$ of fortified RCPB $\mathrm{pH} 5$ agar, the salts and the RCA agar (weighed according to the manufacturer's instructions) were dissolved in $219 \mathrm{~mL}$ Milli-Q water (Millipore ${ }^{\circledR}$ ) and mixed with $45 \mathrm{~mL}$ liver infusion, before adjusting the $\mathrm{pH}$ to 5 and sterilising at $121^{\circ} \mathrm{C} / 15$ minutes. Simultaneously, the Prussian Blue dye $(0.03 \%)$ was dissolved in $36 \mathrm{~mL}$ water and also sterilised at $121^{\circ} \mathrm{C} / 15$ minutes. The mixture of the dye with the agar was carried out in a laminar flow chamber, in the same way as the RCPB pH5 agar. In a second experiment, the RCPB pH5 agar was only fortified with the liver extract, without the addition of the salts (RCPB pH5-Liver).

\section{Inoculum activation}

The inoculum of $B$. animalis $\mathrm{Bb} 12$ was prepared in milk powder, reconstituted to $12 \%$ solids, supplemented with $1 \%$ yeast extract and sterilised at $115^{\circ} \mathrm{C}$ for 10 minutes. The freeze- 
dried culture of $B$. animalis $\mathrm{Bb} 12$ was incubated at $37^{\circ} \mathrm{C}$ for 6 hours. The inoculum of the yoghurt cultures was prepared with skimmed milk powder, reconstituted to $11 \%$ solids and sterilised in an autoclave at $115^{\circ} \mathrm{C}$ for 10 minutes. The freeze-dried cultures of $S$. thermophilus and L. bulgaricus were activated at $37^{\circ} \mathrm{C}$ until coagulation of the milk (6-7 hours for $S$. thermophilus and 14-15 hours for L. bulgaricus).

\section{Evaluation of the agars RCPB pH5, MRS-LP and fortified RCPB} pH5 for counts made after the refrigerated storage of yoghurt

The media RCPB pH5, MRS-LP and fortified RCPB pH5 were tested as following:

a) pure culture test: the activated inoculum of $B$. animalis $\mathrm{Bb}$ 12, S. thermophilus TA 040 and L. bulgaricus LB 340 were enumerated on RCPB pH5, MRS-LP and fortified RCPB pH5. The $B$. animalis $\mathrm{Bb} 12$ cultures were also enumerated on MRS agar used as standard medium. For enumeration of each pure culture, each inoculum was decimally diluted in $0.1 \%$ peptone water to $10^{-6}$ and a $0.1 \mathrm{~mL}$ aliquot of each dilution being plated on the agar under study by the surface spread technique. The $10^{-4}$ to $10^{-6}$ dilutions were plated on the RCPB pH5 agar and in MRS standard medium for Bifidobacterium. The $10^{-1}$ to $10^{-6}$ dilutions were plated on the selective MRS$\mathrm{LP}$ agar and the fortified RCPB pH5 agar. The same inoculum of each microrganism were used in each medium studied and the plates of each medium were incubated at the same conditions $\left(37^{\circ} \mathrm{C}\right.$ for 72 hours $)$ in the same anaerobic jars using Anaerogen ${ }^{\circledR}$ anaerobiosis generator from Oxoid.

b) yoghurt test: a probiotic yoghurt were produced incubating B. animalis $\mathrm{Bb} 12$ (1\% inoculum), S. thermophilus TA 040 ( $1 \%$ inoculum) and L. bulgaricus LB 340 ( $1 \%$ inoculum) at $37^{\circ} \mathrm{C}$ until $\mathrm{pH} 4,6$ was reached and stored at $7^{\circ} \mathrm{C}$ for 30 days. After 30 days of storage time, B. animalis $\mathrm{Bb} 12$ were enumerated on RCPB pH5, MRS-LP and fortified RCPB pH5 to evaluate the performance of each medium for Bifidobacterium counting after refrigerated storage of yoghurt. RCPB pH5 was used as standard medium for counting $B$. animalis $\mathrm{Bb} 12$ and $L$. bulgarucius in yoghurt because this medium was already described by Rybka and Kailasapath (10) for this purpose.

After incubation under anaerobiosis, the RCPB pH5 and fortified RCPB pH5 plates were exposed to air for a few hours to allow for the formation of a blue halo around the L. bulgaricus colonies. After incubation, the media were analysed with respect to differentiated or selective development and with respect to cell recovery of $B$. animalis $\mathrm{Bb} 12$, being compared with the standard MRS agar in the case of the pure culture and with the RCPB pH5 agar for the probiotic yoghurt (Fig. 1).

\section{Effect of adding salts in the fortification of RCPB pH5 agar}

The following experiment was designed in order to evaluate the addition of salts $\left(\mathrm{KH}_{2} \mathrm{PO}_{4}, \mathrm{~K}_{2} \mathrm{HPO}_{4}, \mathrm{FeSO}_{4} 7 \mathrm{H}_{2} \mathrm{O}\right.$,
$\mathrm{MnSO}_{4} \mathrm{H}_{2} \mathrm{O}$ and $\mathrm{MgSO}_{4} 7 \mathrm{H}_{2} \mathrm{O}$ ) on the performance of fortified RCPB pH5 agar: a probiotic yoghurt was produced incubating $1 \%$ of each activated inoculum of $B$. animalis $\mathrm{Bb} 12, S$. thermophilus A and L. bulgaricus 18 until pH 4,6 was reached. The count of Bifidobacterium cells was carried out after 30 days of refrigerated storage of yoghurt at $7^{\circ} \mathrm{C}$ in $\mathrm{RCPB} \mathrm{pH} 5$ agar fortified with salts and infusion of dehydrated liver and in $\mathrm{RCPB}$ pH5 fortified with only the dehydrated liver infusion (RCPB pH5-Liver).

\section{Statistical analysis}

The Tukey test was applied to check for differences in microbial recovery in the media studied using the Software Statistica 5.0. All trials were made in triplicate.

\section{RESULTS AND DISCUSSION}

\section{Evaluation of the agars RCPB pH5, MRS-LP and fortified RCPB} pH5 for counts made after the refrigerated storage of yoghurt

Table 1 shows the recovery of $B$. animalis $\mathrm{Bb} 12, S$. thermophilus and L. bulgaricus in each medium studied when in pure culture and the recovery of $B$. animalis $\mathrm{Bb} 12$ counts in MRS medium used as standard for pure culture test and $B$. animalis $\mathrm{Bb} 12$ counts in yoghurt after 30 days of refrigerated storage. The $B$. animalis $\mathrm{Bb} 12$ count in all media under study in pure culture test was not significantly different from that in the standard MRS agar $(\mathrm{p}<0.05)$. Pure cultures of $S$. thermophilus were completely inhibited in the $\mathrm{RCPB} \mathrm{pH} 5$ and fortified RCPB $\mathrm{pH} 5$ agars, probably due to the low $\mathrm{pH}$ value, as described by Rybka and Kailasapathy (10). In previous studies carried out in the author's laboratory, it was seen that $S$. thermophilus usually developed to about $8-9 \log \mathrm{CFU} / \mathrm{mL}$ in

Table 1. S. thermophilus, L. bulgaricus and B. animalis $\mathrm{Bb} 12$ counts $(\log \mathrm{CFU} / \mathrm{mL})$ in the various media studied in pure cultures $(\mathrm{Bb} 12, \mathrm{St}$ and $\mathrm{Lb})$ and B. animalis $\mathrm{Bb} 12$ in yoghurt (Yoghurt) after 30 days refrigerated storage.

\begin{tabular}{ccccc}
\hline Cultures & MRS & RCPB pH5 & MRS-LP & $\begin{array}{c}\text { Fortified } \\
\text { RCPB pH5 }\end{array}$ \\
\hline Bb12 $^{\mathrm{a}}$ & $9,47 \pm 0,12$ & $9.54 \pm 0,25^{*}$ & $9.49 \pm 0,21^{*}$ & $9.53 \pm 0,22^{*}$ \\
$\mathrm{St}^{\mathrm{a}}$ & nd & ng & $5.19 \pm 0,15$ & $\mathrm{ng}$ \\
$\mathrm{Lb}^{\mathrm{a}}$ & nd & $8.55 \pm 0,15$ & $7.60+0,20$ & $6.50 \pm 0,18$ \\
Yoghurt $^{\mathrm{b}}$ & nd & $6.40 \pm 0,07$ & $6.41 \pm 0,18^{* *}$ & $6.60 \pm 0,12^{* *}$ \\
\hline
\end{tabular}

${ }^{\mathrm{a}} \mathrm{Bb} 12$ - B. animalis $\mathrm{Bb} 12$ count in pure culture, $\mathrm{St}-\mathrm{S}$. thermophilus TA 040 count in pure culture and Lb - L. bulgaricus LB 340 count in pure culture. ${ }^{\mathrm{b}} \mathrm{B}$. animalis $\mathrm{Bb} 12$ count in yoghurt after 30 days storage.* The counts did not differ from the count in the control MRS agar at $\mathrm{p}$ $<0.05$. $^{*}$ The counts did not differ significantly from the count in RCPB pH5 at $\mathrm{p}<0.05 . n g$ - no growth.nd - not determined. 
yoghurt at the conditions used in this study, so a partial inhibition of S. thermophilus in MRS-LP agar can be seen at Table 1 by the low count obtained in this agar $(5.19 \log \mathrm{CFU} / \mathrm{mL})$.

The MRS-LP agar caused a reduction of approximately $1 \log$ in the L. bulgaricus LB 340 count when compared to the recovery of this organism in RCPB pH5 agar, which is not an inhibitory media for $L$. bulgaricus and can be used for the differential count of this microorganism in yoghurt (10). Although the level of reduction was satisfactory for the selective count of Bifidobacterium in this study, it is known that the sensitivity to antimicrobial agents depends on the strain of microorganism used, and thus a reduction of only 1 logarithmic cycle in the number of Lactobacillus cells makes the use of MRS-LP agar risky, since this agar is selective and not differential and there is no difference between the colonies of Bifidobacterium and Lactobacillus strains in this medium. Surprisingly, the fortified RCPB pH5 agar also presented a reduction in the L. bulgaricus count, of about 2 logarithmic cycles, when this was inoculated as a pure culture $(6.50 \log \mathrm{CFU} / \mathrm{mL})$ when compared to the RCPB pH5 agar (8.55 log CFU/mL).

In yoghurt, the $B$. animalis colonies developed presenting a mean diameter of about 1 to $2 \mathrm{~mm}$ on the fortified RCPB pH5 agar after refrigerated storage, although on the $\mathrm{RCPB} \mathrm{pH} 5$ agar they could only be seen with the aid of a stereoscope being magnified at 15 to 20 times. On the MRS-LP agar, the B. animalis colonies presented a diameter of about $0.1 \mathrm{~mm}$.

After refrigerated storage, the $B$. animalis counts in RCPB pH5, MRS-LP and in fortified RCPB pH5 agar was not significantly different at $\mathrm{p}<0.05$ (Table 1). Although the RCPB pH5 agar showed good recovery of the cells after the storage period of the yoghurt, the Bifidobacterium colonies could only be visualised with the aid of a stereoscope, making the count difficult and prone to errors. Payne et al. (9) did not manage to

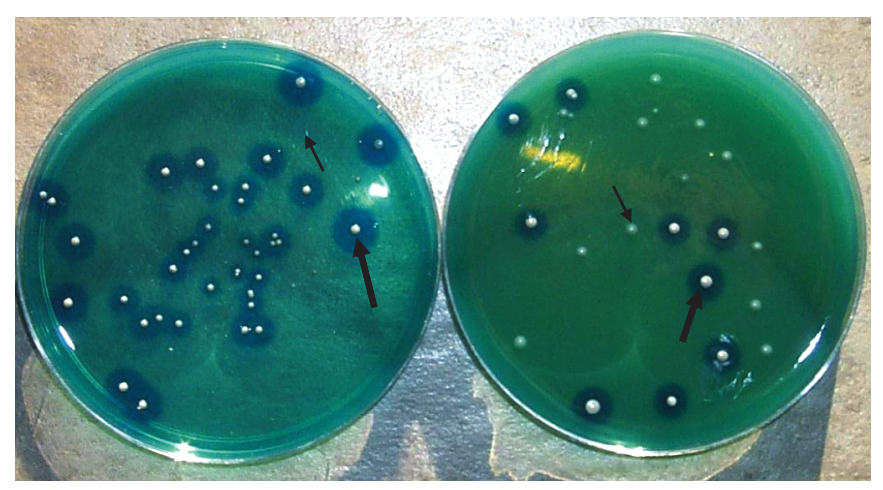

Figure 1. Petri dishes for counting B. animalis $\mathrm{Bb} 12$ (narrow arrows, white colonies) after 30 days of storage at $7^{\circ} \mathrm{C}$. White colonies of $L$. bulgaricus surrounded by blue halo (wide arrows). Left-RCPBpH5. Right-RCPB pH5-Liver: RCPB pH5 fortified with $150 \mathrm{~mL} / \mathrm{L}$ of liver infusion. distinguish the species of Bifidobacterium in relation to the yoghurt cultures, when mixed cultures were inoculated onto RCPB agar. The fortification of RCPB pH5 in this study with salts and a liver infusion overcame this problem, allowing the Bifidobacterium colonies to develop to a diameter of about 1 to $2 \mathrm{~mm}$, making the counting and differentiation of the colonies much easier. The MRS-LP agar also presented selectivity and could be used for the count of Bifidobacterium during the refrigerated storage of yoghurt, although the final diameter of the colonies is much smaller than that found using the fortified RCPB pH5 (1 to $2 \mathrm{~mm}$ against $0.1 \mathrm{~mm}$ in the MRS-LP medium)

\section{Effect of the addition of salts in the fortification of RCPB pH5 agar}

Table 2 shows the effect of the addition of salts $\left(\mathrm{KH}_{2} \mathrm{PO}_{4}\right.$, $\mathrm{K}_{2} \mathrm{HPO}_{4}, \mathrm{FeSO}_{4} 7 \mathrm{H}_{2} \mathrm{O}, \mathrm{MnSO}_{4} \mathrm{H}_{2} \mathrm{O}, \mathrm{MgSO}_{4} 7 \mathrm{H}_{2} \mathrm{O}$ ) on the performance of the fortified RCPB pH5 agar. There was no difference $(\mathrm{p}<0.05)$ in the Bifidobacterium counts between the two types of fortification (with and without salts addition), showing that the presence of the salts did not affect the performance of the fortified agar. Thus the addition of dehydrated liver extract alone was sufficient for the RCPB pH5 agar to considerably increase its power to differentiate the Bifidobacterium during refrigerated storage of the yoghurt, when these cells were more stressed due to the long time of exposure at acid $\mathrm{pH}$ of yoghurt and low temperatures of the refrigerated storage.

Concluding the three culture media evaluated (RCPB pH5, MRS-LP and fortified RCPB $\mathrm{pH} 5$ ) presented the capacity to count $B$. animalis $\mathrm{Bb} 12$ in yoghurt after refrigerated storage. However, in RCPB pH5 agar, the Bifidobacterium colonies were extremely small and could only be counted with the aid of a stereoscope, making the count difficult and prone to errors. The MRS-LP agar showed good selectivity for Bifidobacterium and could be used to count this microorganism in yoghurt after refrigerated storage; however, the count of Bifidobacterium on this medium could be risky, as this medium only inhibited about 1 logarithmic cycle of $L$. bulgaricus cells when in pure culture. Fortified RCPB pH5 agar also presented the same cell recovery

Table 2. Bifidobacterium animalis subsp. lactis Bb 12 counts $(\log \mathrm{CFU} / \mathrm{mL})$ in RCPB pH5 agar with diverse fortifications.

\begin{tabular}{ccc}
\hline RCPB pH5 & $\begin{array}{c}\text { RCPB pH5 agar } \\
\text { fortified with liver } \\
\text { extract and salts* }\end{array}$ & $\begin{array}{c}\text { RCPB pH5 agar } \\
\text { fortified with liver } \\
\text { extract (RCPB pH5- } \\
\text { Liver agar) }\end{array}$ \\
\hline $7.30 \pm 0.40$ & $7.24 \pm 0.51$ & $7.41 \pm 0.59$ \\
\hline$* \mathrm{KH}_{2} \mathrm{PO}_{4}(1 \mathrm{~g} / \mathrm{L}), \mathrm{K}_{2} \mathrm{HPO}_{4}(1 \mathrm{~g} / \mathrm{L}), \mathrm{FeSO}_{4} 7 \mathrm{H} 2 \mathrm{O}(0.01 \mathrm{~g} / \mathrm{L})$, \\
$\mathrm{MnSO}_{4} \mathrm{H}_{2} \mathrm{O}(0.01 \mathrm{~g} / \mathrm{L})$ and $\mathrm{MgSO}_{4} 7 \mathrm{H}_{2} \mathrm{O}(0.2 \mathrm{~g} / \mathrm{L})$.
\end{tabular}


of Bifidobacterium as RCPB pH5 agar and its fortification with $150 \mathrm{~mL} / \mathrm{L}$ of dehydrated liver extract resulted in a significant increase in the diameter of the Bifidobacterium colonies, making the count easier and reliable after the refrigerated storage of yoghurt, when Bifidobacterium cells are more stressed.

\section{ACKNOWLEDGEMENTS}

To Chr. Hansen Indústria and Comércio Ltda. for the donation of Bifidobacterium animalis $\mathrm{Bb} 12$. To Rhodia Food (current Danisco Brasil Ltda, Cotia, SP) for donation of Streptococcus thermophilus TA 040 and Lactobacillus delbrueckii subsp. bulgaricus LB 340. To Wiesby Starter Cultures \& Media (current Danisco Brasil Ltda, Cotia, SP) for donation of S. thermophilus A and Lactobacillus delbrueckii subsp. bulgaricus 18. To FAPESP for financial support.

\section{RESUMO}

\section{Avaliação de meios de cultura para contagem de Bifidobacterium animalis subsp. lactis Bb $12 \mathrm{em}$ iogurte após a estocagem refrigerada}

O meio RCPB pH5 tem sido considerado uma boa opção para a contagem de Bifidobacterium em iogurte. Entretanto, durante a estocagem refrigerada do iogurte é extremante difícil a contagem deste microrganismo devido ao pequeno diâmetro desenvolvido pelas colônias de Bifidobacterium neste meio, sendo que a sua contagem somente se torna possível com o auxílio de um estereoscópio. Outro meio, MRS-LP, também tem sido recomendado para a contagem de Bifidobaterium em iogurte. Este estudo avaliou a suplementação do meio RCPB pH5 com extrato de fígado desidratado e com os sais $\mathrm{KH}_{2} \mathrm{PO}_{4}$, $\mathrm{K}_{2} \mathrm{HPO}_{4}, \mathrm{FeSO}_{4} 7 \mathrm{H}_{2} \mathrm{O}, \mathrm{MnSO}_{4} \mathrm{H}_{2} \mathrm{O}$ e $\mathrm{MgSO}_{4} 7 \mathrm{H}_{2} \mathrm{O}$, visando melhorar a diferenciação de Bifidobacterium em iogurte durante a estocagem refrigerada e também avaliou a contagem seletiva de Bifidobacterium em iogurte usando o meio MRS-LP. O meio MRS-LP apresentou a mesma recuperação de células que o meio RCPB pH5, usado como padrão, após 30 dias de estocagem refrigerada do iogurte, sendo considerado uma boa opção para a contagem de Bifidobacterium em iogurtes durante a estocagem refrigerada. O meio RCPB pH5 fortificado também apresentou a mesma recuperação de células de Bifidobacterium que o meio padrão RCPB pH5; entretanto, a adição de extrato de fígado desidratado aumentou consideravelmente o diâmetro das colônias de Bifidobacterium, tornando a diferenciação destas bastante fácil e confiável quando comparadas à sua diferenciação no meio RCPB pH5 sem a fortificação. A adição dos sais $\left(\mathrm{KH}_{2} \mathrm{PO}_{4}, \mathrm{~K}_{2} \mathrm{HPO}_{4}, \mathrm{FeSO}_{4} 7 \mathrm{H}_{2} \mathrm{O}, \mathrm{MnSO}_{4} \mathrm{H}_{2} \mathrm{O}\right.$ e $\mathrm{MgSO}_{4} 7 \mathrm{H}_{2} \mathrm{O}$ ) não exerceu influência no desempenho do meio $\mathrm{RCPB}$ pH5.

Palavras-chave: contagem, Bifidobacterium, iogurte, estocagem refrigerada

\section{REFERENCES}

1. Beehrens, H. (1990). An elective and selective isolation medium for Bifidobacterium spp. Lett. Appl. Microbiol., 11 (3), 155-157.

2. Bomba, A.; Nemcová, R.; Mudronová, D.; Guba, P. (2002). The possibilities of potentiating the efficacy of probiotics. Trends Food Sci. Technol., 13 (4), 121-126.

3. FAO/WHO. Report of a Joint FAO/WHO Expert Consultation on Evaluation of Health and Nutritional Properties of Probiotics in Food Including Powder Milk with Live Lactic Acid Bacteria, Amerian Córdoba Park Hotel, Córdoba, Argentina, 1-4 October, 2001.

4. Ghodussi, H.B.; Robinson, R.K. (1996). Enumeration of starter cultures in fermented milks. J. Dairy Res., 63 (1), 151-158.

5. Lapierre, L.; Undeland, P.; Cox, L. J. (1992). Lithium chloridesodium propionate agar for the enumeration of Bifidobacteria in fermented dairy products. J. Dairy Sci., 75 (5), 1192-1196.

6. Laroia, S.; Martin, J.H. (1991). Methods for enumerating and propagating Bifidobactéria. Cultured Dairy Prod. J., 26 (2), 32-33.

7. Moriya, J.; Fachin, L.; Gândara, A.L.N.; Viotto, W.H. (2006). Evaluation of culture media for counts of Bifidobacterium animalis in the presence of yoghurt bacteria. Braz. J. Microbiol., 37, 510-514.

8. Onggo, I.; Fleet, G.H. (1993). Media for the isolation and enumeration of lactic acid bacteria from yoghurts. Aust. J. Dairy Technol., 48 (2), 89-92.

9. Payne, J.F.; Morris, A.E.J.; Beers, P. (1999). Evaluation of selective media for the enumeration of Bifidobacterium sp. in milk. J. Appl. Microbiol., 86 (2), 353-358.

10. Rybka, S.; Kailasapathy, K. (1996). Media for the enumeration of yoghurt Bacteria. Int. Dairy J., 6 (8-9), 839-850.

11. Vinderola, C.G.; Reinheimer, J.A. (1999). Culture media for the enumeration of Bifidobacterium bifidum and Lactobacillus acidophilus in the presence of yoghurt bacteria. Int. Dairy J., 9 (8), 497-505. 